\title{
ANALYSIS FACTORS THAT AFFECTING THE WORK COMMITMENT OF TEACHERS
}

\author{
Marsofiyati \\ Fakultas Ekonomi, Universitas Negeri Jakarta \\ marsofiyati@unj.ac.id
}

\begin{abstract}
The purpose of this research is to analyze the factors that affecting the work commitment of teachers. The research use descriptive quantitative method. The problem are the teachers who work without commitment, just to teach according to what was ordered by the principal. By having a high work commitment that is evident in the behavior of painstaking work, passionate, integrity of the work, responsibility, and maintain morale as educators. The results are: commitment to working both seen from the achievement an average score of 71.61, completion of the task is the highest factor in teachers' work commitment with an average score of 79.67, and development of self-efficacy is the lowest factor in teachers' work commitment with an average score of 73.00. Suggestions are: schools should give rewards to the teachers who complete the task on time and to sanction teachers who did not complete the task on time, provide education and training to the teachers continuously and sustainably as efforts to develop self-efficacy ofteachers, the teacher involvement in school activities further improved, so that the visible concern for the fate of school teachers and Teacher work program should be set up and executed in accordance with a predetermined plan.
\end{abstract}

Keywords:School, Teacher, Work Commitment

\begin{abstract}
ABSTRAK
Tujuan dari penelitian ini adalah untuk menganalisis faktor-faktor yang mempengaruhi komitmen kerja guru. Penelitian ini menggunakan metode deskriptif kuantitatif. Masalahnya adalah guru yang bekerja tanpa komitmen, hanya untuk mengejar sesuai dengan apa yang diperintahkan oleh Kepala Sekolah. Dengan memiliki komitmen kerja tinggi yang terbukti dalam perilaku kerja yang telaten, bergairah, integritas kerja, tanggung jawab, dan menjaga moral sebagai pendidik. Hasilnya adalah: komitmen untuk bekerja baik dilihat dari prestasi skor rata-rata 71,61, penyelesaian tugas merupakan faktor tertinggi dalam komitmen kerja guru dengan skor rata-rata 79,67 , dan pengembangan self-efficacy merupakan faktor terendah dalam guru. Komitmen kerja dengan skor rata-rata 73.00. Saran adalah: sekolah harus memberikan reward kepada guru yang menyelesaikan tugas tepat waktu dan memberi
\end{abstract}


sanksi kepada guru yang tidak menyelesaikan tugasnya tepat waktu, memberikan pendidikan dan pelatihan kepada para guru secara terus menerus dan berkelanjutan. Upaya untuk mengembangkan self-efficacy of teachers, keterlibatan guru dalam kegiatan sekolah semakin meningkat, sehinga kepedulian terhadap nasib guru sekolah dan program kerja guru harus dilakukan dan dilaksanakan sesuai dengan rencana yang telah ditentukan.

Kata kunci: Sekolah, Guru, Komitmen Kerja

\section{PENDAHULUAN}

Guru merupakan sumberdaya manusia utama yang menentukan maju mundurnya sekolah. Hal ini menuntut guru melaksanakan tugas dengan lebih profesional, yang berarti guru bekerja keras, bekerja sepenuh waktu, bekerja sepenuh hati, disiplin, jujurdan penuh dedikasi demi untuk keberhasilan pekerjaan. Untuk itu, diperlukan adanya pembinaan dan ditumbuhkan kesadaran serta kemampuan kerja yang tinggi. Apabila guru dengan penuh kesadaran bekerja dengan optimal, maka tujuan sekolah lebih mudah tercapai (London, 2002).

Perlu disadari bahwa dalam menjalankan tugas, guru tidak hanya menginginkan uang dan materi sebagai imbalan dari hasil kerja. Keinginan memenuhi kebutuhan-kebutuhan yang lain seperti kebutuhan fisiologis, rasa aman, sosial, rasa memiliki, status dan penghargaan, serta kebutuhan perwujudan atau aktualisasi diri.

Guru yang bekerja tanpa komitmen, hanya mengajar sesuai dengan apa yang diperintahkan oleh kepala sekolah. Guru seperti ini hanya datang ke sekolah, mengajar, dan pulang pada saat jam pelajaran selesai, tanpa mengkaji apa yang telah diajarkan. Jika hal ini terus berjalan, maka tidak ada yang didapat oleh sekolah maupun oleh siswa, karena tidak ada tanggungjawab dalam diri guru tersebut untuk memperbaiki kualitas diri dan mutu pelajaran. Mereka beranggapan bahwa mereka telah mengerjakan tugasnya dengan baik, namun tugas yang mereka kerjakan di atas hanya sebagian kecil dari tugas guru. Tugas guru selain mengajar adalah mendidik, menjadikan siswa memiliki moral dan budi pekerti yang baik dan dapat diterima oleh masyarakat (Hamalik, 2002).

Komitmen kerja merupakan ketertarikan terhadap tujuan dan nilai-nilai yang akan dicapai oleh individu. Komitmen kerja yang tinggi ditandai oleh keinginan kuat untuk tetap menjadi anggota organisasi, kesediaan untuk berusaha sebaik mungkin demi kepentingan organisasi, kepercayaan dan penerimaan yang kuat terhadap nilai-nilai dan tujuan organisasi (Fred, 2006).

Dengan memiliki komitmen kerja tinggi yang nampak dalam perilaku bekerja sungguh-sungguh, bersemangat, serius, memiliki integritas terhadap pekerjaan, bertanggungjawab, dan menjaga moral sebagai pendidik.

Berdasarkan latar belakang masalah tersebut, peneliti tertarik 
untuk meneliti faktor-faktor yang mempengaruhi komitmen kerja guru.

\section{KAJIAN TEORITIK Komitmen Kerja}

Komitmen kerja merupakan ketertarikan terhadap tujuan dan nilai-nilai yang dicapai oleh individu. Dalam dunia kerja, komitmen kerja seseorang terhadap organisasi merupakan faktor yang sangat dibutuhkan, sehingga keberadaannya harus dipahami dan diperhatikan dengan sungguhsungguh (Arni Muhammad, 1996). Komitmen pada intinya mengarahkan seseorang untuk mengkategorikan perbedaan-perbedaan individu dalam masalah nilai dan motif secara lebih sederhana.

Scott \& Burroughs (Bishop, 2000) melihat komitmen sebagai "commitment as the relative strength of an individual's identification with, and involvement in an organization." Dari pendapat Scott \& Burroughs tersebut dapat diketahui bahwa komitmen merupakan kekuatan relatif dan identifikasi individu bersama dan keterlibatannya dengan organisasi.

Terkait dengan komitmen, Hersey (Hersey, 1996), mengidentifikasi dan menemukan lima model, yaitu; (1) komitmen kepada pelanggan (commitment to the customer); (2) komitmen kepada organisasi (commitment to the organization); (3) komitmen kepada diri (commitment to self); (4) komitmen kepada orang-orang (commitment to people), dan (5) komitmen kepada tugas (commitment to task). Komitmen kepada tugas berarti berkonsentrasi kepada pelaksanaan tugas atau pekerjaan.

Selain itu, komitmen juga bercirikan adanya: (1) kepercayaan yang kuat, penerimaan terhadap tujuan, dan nilai organisasi; kesiapan untuk bekerja keras, serta (3) keinginan yang kuat untuk bertahan dalam organisasi (John M, 2007). Dengan demikian komitmen individu terhadap organisasi bukan merupakan suatu hal yang terjadi secara sepihak. Dalam hal ini organisasi dan pegawai (individu) harus secara bersama-sama menciptakan kondisi yang kondusif untuk mencapai komitmen yang diinginkan (Handoko, 2000). Sebagai contoh: seseorang yang semula kurang memiliki komitmen, namun setelah bekerja ternyata selain ia mendapat imbalan sesuai dengan ketentuan yang berlaku ternyata didapati adanya hal-hal yang menarik dan memberikan kepuasan.Seseorang yang memiliki komitmen, akan bekerja dengan sungguh-sungguh, bersemangat, dan menjalin kerjasama yang baik, agar tercapai tujuan organisasi serta memiliki keberpihakan terhadap organisasi (Fred, 2006).

Robbins (2006) the commitment goes beyond the enjoyment of work for its intrinsic motivation and income. De Porter dan Hernacki ( (Robbins., 2006) mengatakan bahwa komitmen adalah tekad yang kuat, yang mendorong untuk mewujudkannya, terlepas dari beberapa rintangan yang mungkin dihadapi.

Komitmen merupakan suatu tindakan seseorang yang me- 
nginginkan perubahan, dan percaya bahwa yang dapat melakukan perubahan adalah diri sendiri. Adapun Zone (2000) menekankan bahwa komitmen karyawan merupakan keharusan memberikan yang dapat dilakukan dalam bekerja, dan sebaliknya organisasi juga harus dapat meningkatkan komitmen dan dedikasi para karyawan apabila menghendaki komitmen, dedikasi dan kerja keras dari karyawan.

Komitmen terbentuk melalui sebuah proses yang terdiri dari tiga tahap. Komitmen dapat muncul pada awal dari pekerjaan. Individu tertentu mempunyai potensi komitmen yang kuat pada suatu organisasi dan dengan cepat menyatukan perasaaannya dengan perusahaan. Seperti yang nampak pada gambar di halaman berikut bahwa faktor-faktor yang muncul di awal situasi pekerjaan dapat mempengaruhi tingkat komitmen (Jack, 2000).

Menurut Zone (2000) Komitmen kerja dipengaruhi oleh adanya imbalan dari organisasi yang berupa: (a) kepentingan pribadi (personal importence). Pengalaman orang dipandang sebagai anggota yang berharga dan produktif bagi organisasi. (b) Realisasi dan harapan (realization of expectations). Organisasi dapat memenuhi janji untuk perbaikan anggota. (c) Tantangan pekerjaan (job challenge). Penugasan pekerjaan yang menantang, menarik, dan pemberian imbalan, dapat memperkuat komitmen.

Esensi komitmen adalah menjadikan sasaran karyawan dan sasaran organisasi menjadi satu dan sama, keterikatan yang kuat dengan sasaran kelompok. Mereka yang menghargai dan berpegang teguh pada misi organisasi bersedia untuk tidak hanya berusaha sepenuh hati atas nama organisasi, tetapi juga berkorban bilamana diperlukan (Gibson, 1997).

Dari uraian di atas dapat diperoleh gambaran bahwa komitmen kerja dapat terbangun dalam diri guru, apabila organisasi sekolah memiliki tujuan atau sasaran yang selaras dengan tujuan guru, dan terdapat kesepahaman tujuan yang ingin dicapai. Sehingga guru merasa memiliki dan bertanggungjawab terhadap pencapaian tujuan organisasi, yang ditunjukkan dengan perilaku kerja yang baik dan senantiasa ingin memberikan yang berkualitas dalam menjalankan tugas.

Berdasarkan beberapa pendapat para ahli yang telah disampaikan tersebut maka dapat disimpulkan bahwa yang dimaksud dengan komitmen kerja adalah serangkaian tanggungjawab pribadi dalam pekerjaan untuk memberikan hasil terbaik agar tujuan sekolah dapat tercapai tanpa paksaan dari pihak manapun.

\section{Faktor-faktor yang Mempengaruhi Komitmen Kerja}

Seorang guru akan memiliki komitmen kerja yang tinggi apabila dilibatkan dalam segala kegiatan sekolah, baik dalam perencanaan dan penyusunan program sekolah maupun dalam perencanaan dan penyusunan anggaran sekolah. Mendapat dukungan dari kepala sekolah dalam melaksanakan tugas 
terutama bila menghadapi kendalakendala dan permasalahan, sehingga tanpa ada instruksi pun guru dengan sadar dan serius bekerja agar tujuan sekolah dapat tercapai.

Komitmen seorang guru terlahir karena guru bertanggungjawab terhadap siswa, sekolah, orang tua siswa dan lingkungan sekitar. Oleh karena itu seorang guru yang memiliki komitmen yang kuat akan tetap bertahan kendati menghadapi tekanan pekerjaan, maupun pendapatan yang tidak sesuai dengan jam yang panjang demi kesetiaan terhadap organisasi.

\section{METODOLOGI PENELITIAN}

Tempat penelitian ini di SMK Cyber Media Utama, Kabupaten Bogor, Jawa Barat dengan unit analisis dalam penelitian ini adalah kepala sekolah, guru-guru dan administrator sekolah, sebanyak 18 orang.

Penelitian ini menggunakan metode deskriptif yang bersifat kuantitatif (Arikunto, 2005). Pengumpulan data dengan menggunakan kuesioner dan observasi langsung. Kemudian data diolah dan dianalisis secara deskriptif yang disajikan dalam bentuk uraian singkat, bagan, hubungan antarkategori, tabel, dan diagram.

\section{HASIL DAN PEMBAHASAN}

Berikut ini faktor-faktor yang mempengaruhi komitmen kerja guru,yang dianalisis oleh peneliti:

1. Penyelesaian tugas
2. Kesungguhan dalam bekerja

3. Keterlibatan dalam pekerjaan

4. Pengembangan kemampuan diri

5. Perilaku kerja yang baik

6. Keinginan memberikan yang terbai

7. ketercapaian tujuan sekolah

Nilai empiris faktor-faktor yang mempengaruhi komitmen kerja bervariasi antara 56 sampai dengan 83, dengan rentang nilai sebesar 27. Berdasarkan hasil penghitungan statistik deskriptif, diperoleh nilai rata-rata 71,61 , dan standar deviasi 6,83 .

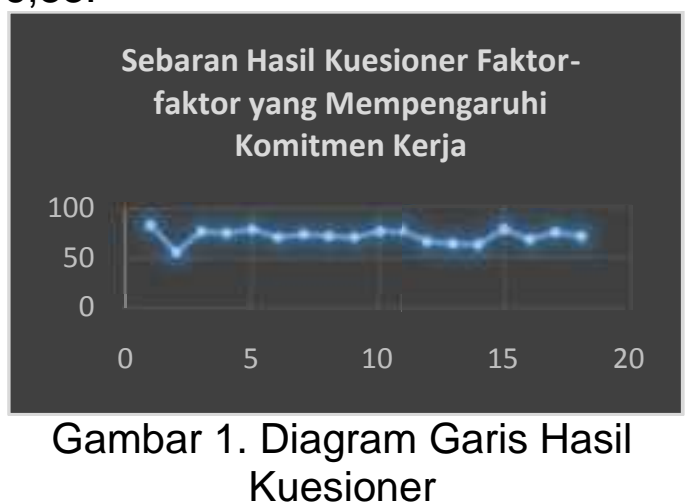

Berdasarkan data pada histogram di atas, diketahui bahwa sebanyak 8 responden $(44,44 \%)$ di SMK Cyber Media Utama, Kabupaten Bogor, Jawa Barat mempunyai komitmen kerja berada pada kategori di bawah rata-rata; dan 10 responden $(55,56 \%)$ berada pada kategori rata-rata ke atas.

Secara umum, persentase penyebaran nilai pada masingmasing variabel Komitmen Kerja dapat dilihat pada Diagram 2 berikut. 


\section{Rerata Nilai Faktor-Faktor Komitmen Kerja

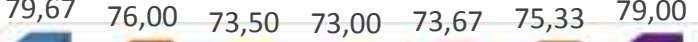 \\ 80,00 \\ 60,00
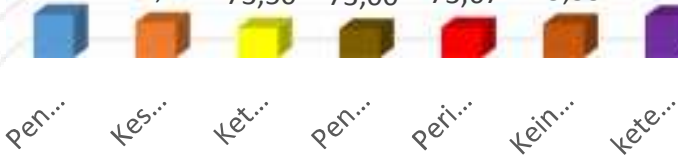

Gambar 2. Rerata Nilai Faktor-Faktor Komitmen Kerja

Berdasarkan data pada gambar 2 di atas, dapat diketahui bahwa faktor Penyelesaian tugas merupakan faktor yang memperoleh nilai paling tinggi, yaitu sebesar 79,67, sedangkan faktor pengembangan kemampuan diri memperoleh nilai paling rendah, yaitu sebesar 73,00. Untuk melihat nilai res-ponden pada masing-masing faktor yang mempengaruhi Komitmen Kerja, diuraikan sebagai berikut.

\section{a. Penyelesaian Tugas}

Pada faktor penyelesaian tugas, nilai total yang diperoleh adalah 267 sedangkan nilai maksimal adalah 270. Dengan demikian, persentase yang diperoleh adalah $89,00 \%$. Apabila dibandingkan dengan tabel penilaian persentase maka penyelesaian tugas di SMK Cyber Media Utama, Kabupaten Bogor, Jawa Barat termasuk kedalam kategori tinggi. Secara lebih lengkap, lihat pada tabel 1 berikut:

Tabel 1. Nilai Penyelesaian Tugas

\begin{tabular}{l|l|r|r|r|r}
\hline \multicolumn{2}{c|}{ Deskripsi } & $\mathbf{1}$ & \multicolumn{1}{c|}{$\mathbf{2}$} & \multicolumn{1}{c|}{$\mathbf{3}$} & \multicolumn{1}{c}{ Total } \\
\hline $\mathrm{N}$ & Valid & 18 & 18 & 18 & 18 \\
\hline Minimum & Missing & 0 & 0 & 0 & 0 \\
\hline Maximum & & 3,00 & 3,00 & 2,00 & 54,00 \\
\hline Sum & & 5,00 & 5,00 & 5,00 & 270,00 \\
\hline Prosentase Nilai & & 82,00 & 79,00 & 78,00 & 239,00 \\
\hline
\end{tabular}

Dengan nilai yang didapat sebesar $88,52 \%$, dapat dikatakan bahwa penyelesaian tugas telah berjalan dengan baik.

\section{b. Kesungguhan dalam Bekerja}

Pada faktor kesungguhan dalam bekerja, nilai total yang diperoleh adalah 152 sedangkan nilai maksimal adalah 180. Dengan demikian, persentase yang diperoleh adalah 84,44\%. Apabila dibandingkan dengan tabel penilaian persentase maka faktor kesungguhan dalam bekerja termasuk dalam kategori tinggi. Secara lebih lengkap, lihat pada tabel 2 berikut.

Tabel 2. Nilai Kesungguhan dalam Bekerja

\begin{tabular}{l|l|r|r|r}
\hline \multicolumn{2}{c}{ Deskripsi } & \multicolumn{1}{c|}{$\mathbf{4}$} & \multicolumn{1}{c|}{5} & \multicolumn{2}{c}{ Total } \\
\hline $\mathrm{N}$ & Valid & 18 & 18 & 18 \\
\hline & Missing & 0 & 0 & 0 \\
\hline Minimum & & 2,00 & 3,00 & 36,00 \\
\hline
\end{tabular}




\begin{tabular}{l|r|r|r|r}
\hline Maximum & & 5,00 & 5,00 & 180,00 \\
\hline Sum & & 77,00 & 75,00 & 152,00 \\
\hline Prosentase Nilai & $85,56 \%$ & $83,33 \%$ & $84,44 \%$ \\
\hline
\end{tabular}

Dari temuan penelitian didapat bahwa faktor kesungguhan dalam bekerja guru beraneka ragam, hal tersebut terlihat dari responden yang mengatakan kurang bersungguh-sungguh dalam bekerja, mengajar belum tepat waktu, dan mengajar belum sesuai dengan waktu yang telah ditetapkan.

\section{c. Keterlibatan dalam Pekerjaan}

Keterlibatan dalam pekerjaan memiliki nilai total yang diperoleh sebesar 147 sedangkan nilai maksimal adalah 180. Dengan demikian, persentase yang diperoleh adalah $81,67 \%$. Apabila dibandingkan dengan tabel penilaian persentase maka keterlibatan dalam pekerjaan tergolong dalam kategori tinggi. Secara lebih lengkap, dapat dilihat pada tabel 3 berikut:

Tabel 3. Nilai Keterlibatan dalam Pekerjaan

\begin{tabular}{l|l|r|r|r}
\hline \multicolumn{2}{c|}{ Deskripsi } & \multicolumn{1}{c|}{$\mathbf{6}$} & \multicolumn{1}{c|}{7} & \multicolumn{1}{c}{ Total } \\
\hline $\mathrm{N}$ & Valid & 18 & 18 & 18 \\
\hline Minimum & Missing & 0 & 0 & 0 \\
\hline Maximum & & 2,00 & 3,00 & 36,00 \\
\hline Sum & & 5,00 & 5,00 & 180,00 \\
\hline Prosentase Nilai & & 66,00 & 81,00 & 147,00 \\
\hline
\end{tabular}

Dari tabel tersebut dapat dilihat bahwa keterlibatan guru dalam pekerjaan relatif tinggi.

\section{d. Pengembangan Kemampuan Diri}

Pengembangan kemampuan diri memiliki nilai total yang diperoleh sebesar 146, sedangkan

Tabel 4. Nilai Pengembangan Kemampuan Diri

\begin{tabular}{l|l|r|r|r}
\hline \multicolumn{2}{c|}{ Deskripsi } & \multicolumn{1}{c|}{$\mathbf{8}$} & \multicolumn{1}{c|}{$\mathbf{9}$} & \multicolumn{1}{r}{ Total } \\
\hline $\mathrm{N}$ & Valid & 18 & 18 & 18 \\
\hline & Missing & 0 & 0 & 0 \\
\hline Minimum & & 2,00 & 2,00 & 36,00 \\
\hline Maximum & & 5,00 & 5,00 & 180,00 \\
\hline Sum & & 73,00 & 73,00 & 146,00 \\
\hline Prosentase Nilai & & $81,11 \%$ & $81,11 \%$ & $81,11 \%$ \\
\hline
\end{tabular}

Dari temuan penelitian diperoleh hasil bahwa pengem- nilai maksimalnya adalah 180 . Artinya, persentase yang diperoleh adalah sebesar $81,11 \%$. Dengan demikian, faktor pengembangan kemampuan diri tergolong dalam kategori tinggi. Secara lebih lengkap, dapat dilihat pada tabel 4 berikut: 
ngembangan kemampuan diri merupakan faktor yang memiliki nilai terendah yaitu 73,00 . Hal tersebut disebabkan pihak sekolah belum melaksanakan kegiatan pengembangan diri secara rutin dan sesuai program yang telah ditetapkan.

\section{e. Perilaku Kerja yang Baik}

Hasil temuan yang diperoleh pada faktor perilaku kerja yang baik dapat dilihat dari tabel 5 berikut:

Tabel 5. Nilai Perilaku Kerja yang Baik

\begin{tabular}{l|l|r|r|r|r}
\hline \multicolumn{2}{c|}{ Deskripsi } & \multicolumn{1}{c|}{10} & \multicolumn{1}{c|}{11} & \multicolumn{1}{c|}{12} & \multicolumn{1}{c}{ Total } \\
\hline $\mathrm{N}$ & Valid & 18 & 18 & 18 & 18 \\
\hline & Missing & 0 & 0 & 0 & 0 \\
\hline Minimum & & 3,00 & 2,00 & 3,00 & 54,00 \\
\hline Maximum & & 5,00 & 5,00 & 5,00 & 270,00 \\
\hline Sum & & 78,00 & 71,00 & 72,00 & 221,00 \\
\hline Prosentase Nilai & & $86,67 \%$ & $78,89 \%$ & $80,00 \%$ & $81,85 \%$ \\
\hline
\end{tabular}

Perilaku kerja yang baik memiliki nilai total yang diperoleh sebesar 221 sedangkan nilai maksimalnya adalah 270. Artinya, persentase yang diperoleh adalah sebesar $81,85 \%$. Dengan demikian, faktor perilaku kerja tergolong dalam kategori baik bila dihubungkan dengan tabel penilaian persentase.

\section{f. Keinginan Memberikan yang Terbaik atau Berkualitas}

Pada faktor keinginan memberikan yang terbaik atau berkualitas, nilai total yang diperoleh adalah 226 sedangkan nilai maksimal adalah 270. Dengan demikian, persentase yang diperoleh adalah $83,70 \%$. Apabila dibandingkan dengan tabel penilaian persentase maka faktor keinginan memberikan yang terbaik atau berkualitas tergolong dalam kategori tinggi. Secara lebih lengkap, lihat pada tabel 6 berikut.

Tabel 6. Nilai Keinginan Memberikan yang Terbaik

\begin{tabular}{l|l|r|r|r|r}
\hline \multicolumn{2}{c|}{ Deskripsi } & \multicolumn{1}{c|}{13} & \multicolumn{1}{c|}{$1 \mathbf{1 4}$} & \multicolumn{1}{c|}{ 15 } & \multicolumn{1}{c}{ Total } \\
\hline $\mathrm{N}$ & Valid & 18 & 18 & 18 & 18 \\
\hline Minimum & Missing & 0 & 0 & 0 & 0 \\
\hline Maximum & & 3,00 & 2,00 & 1,00 & 54,00 \\
\hline Sum & & 5,00 & 5,00 & 5,00 & 270,00 \\
\hline Prosentase Nilai & & 80,00 & 73,00 & 73,00 & 226,00 \\
\hline
\end{tabular}

Dari temuan penelitian diperoleh hasil keinginan memberikan yang terbaik atau berkualitas di SMK Cyber Media Utama, Kabupaten Bogor, Jawa Barat yang merupakan unsur penting dalam Komitmen Kerja, dan hal tersebut harus terus diupayakan agar komitmen kerja dapat optimal.

\section{g. Ketercapaian tujuan sekolah}

Pada faktor ketercapaian tujuan sekolah, nilai total yang diperoleh adalah 158 sedangkan nilai maksimal adalah 180. Dengan 
demikian, persentase yang diperoleh adalah $87,78 \%$. Jika dibandingkan dengan tabel penilaian persentase maka faktor ke- tercapaian tujuan sekolah tergolong dalam kategori tinggi. Secara lebih lengkap, dapat dilihat pada tabel 7 berikut:

Tabel 7. Nilai Ketercapaian tujuan sekolah

\begin{tabular}{l|l|r|r|r}
\hline \multicolumn{2}{c}{ Deskripsi } & \multicolumn{1}{c|}{16} & \multicolumn{1}{c|}{$\mathbf{1 7}$} & \multicolumn{1}{c}{ Total } \\
\hline $\mathrm{N}$ & Valid & 18 & 18 & 18 \\
\hline & Missing & 0 & 0 & 0 \\
\hline Minimum & & 2,00 & 3,00 & 36,00 \\
\hline Maximum & & 5,00 & 5,00 & 180,00 \\
\hline Sum & & 77,00 & 81,00 & 158,00 \\
\hline & & & & \\
Prosentase Nilai & & $85,56 \%$ & $90,00 \%$ & $87,78 \%$ \\
\hline
\end{tabular}

Dari tujuh faktor yang mempengaruhi komitmen, penyelesaian tugas memperoleh prosentase nilai tertinggi $(88,52 \%)$, diikuti oleh faktor ketercapaian tujuan sekolah $(87,78 \%)$ dan kesungguhan dalam bekerja $(84,44 \%)$. Selanjutnya keinginan memberikan yang terbaik $(83,70 \%)$, perilaku kerja yang baik $(81,85 \%)$, keterlibatan dalam pekerjaan $(81,67 \%)$, dan diakhiri dengan nilai terendah $(81,11 \%)$ pengembangan kemampuan diri dalam komitmen kerja. Artinya penyelesaian tugas yang dilakukan oleh guru merupakan bukti bahwa guru memiliki komitmen kerja sangat tinggi.

\section{HASIL DAN PEMBAHASAN}

\section{Penyelesaian Tugas}

Data penyelesaian tugas dengan indikator penyelesaian tugas tepat waktu, Silabus dan RPP dibuat pada awal pemelajaran dan seluruh pekerjaan administrasi guru disusun dengan rapi berdasarkan temuan penelitian secara empirik dan dibandingkan secara teoridapat ditunjukkan dengan guru sudah menunjukkan itikad baik dalam menyelesaikan tugas tepat waktu. Namun dalam hal penyusunan silabus dan RPP yang harus dibuat pada awal pemelajaran, hampir seluruh guru tidak menyelesaikan pada awal semester. Hal tersebut disebabkan karena pekerjaan yang menumpuk di akhir tahun dan awal tahun seperti ujian akhir semester, ujian nasional, ujian sekolah, ujian praktek, ujian kompetensi, pembimbingan praktek kerja lapangan dan penerimaan murid baru serta masa orientasi peserta didik (MOPD).

Kegiatan-kegiatan tersebut cukup menyita waktu sehingga pekerjaan-pekerjaan yang berhubungan dengan administrasi agak terabaikan. Pada indikator seluruh pekerjaan administrasi guru disusun dengan rapi. Hasil pengamatan, para guru sudah menyusun rapi pekerjaan administrasi yang telah diselesaikan, hal tersebut dapat dilihat dari bank soal dan beberapa hasil pekerjaan siswa yang disusun dengan rapi pada rak arsip guru. 


\section{Kesungguhan dalam Bekerja}

Kesungguhan dalam bekerja memiliki dua indikator, yaitu bersungguh-sungguh dalam mengajarkan peserta didik dan memberikan materi pelajaran sesuai dengan silabus yang dibuat. Pada kedua indikator tersebut, nilai yang didapat adalah 77 dan 75, menandakan bahwa kesungguhan dalam bekerja pada kriteria baik.

Guru bersungguh-sungguh dalam mengajar peserta didik yang rata-rata belum mengenal bagaimana merakit dan menginstal komputer. Saat ini para remaja hanya tahu bagaimana menggunakan komputer dan mengaplikasikan penggunaan komputer dalam kehidupan sehari-hari. Namun para pengguna (user) tidak tahu bagaimana me-maintance komputer dengan baik, seperti menginstal software anti virus atau menginstal software yang menunjang pekerjaan kantor dengan baik. Oleh karena itu pengetahuan yang awam tentang komputer ini merupakan tantangan tersendiri di sekolah yang berbasis teknologi informasi.

Selain itu keterbatasan alat dan perlengkapan juga merupakan suatu hal yang perlu disikapi dengan bijaksana. Walaupun demikian, dari pengamatan peneliti masih ada oknum guru yang hadir tidak tepat waktu dan hanya memberikan tugas kepada peserta didik. Oknum guru tersebut menjadi catatan peneliti untuk menindaklanjuti keberlangsungan guru tersebut di sekolah.

Kesungguhan guru dalam memberikan materi pelajaran sesuai dengan silabus yang dibuat masih dalam kriteria baik, meskipun masih ada beberapa guru yang memberikan materi seadanya tanpa melihat silabus atau menggunakan RPP, karena keterbatasan mereka dalam hal membuat silabus dan RPP.

\section{Keterlibatan dalam Pekerjaan}

Hasil yang didapat untuk Indikator yang berhubungan dengan keterlibatan dalam pekerjaan terdiri dari dengan peduli dengan nasib sekolah dan memantau perkembangan peserta didik memiliki rentang yang cukup jauh. Dalam hal peduli dengan nasib sekolah, guruguru belum menunjukkan kepedulian terhadap nasib sekolah. Rata-rata guru hanya datang untuk mengajar dan langsung pulang setelah pelajaran selesai. Sedangkan dalam hal memantau perkembangan peserta didik, guru memiliki kepedulian yang relatif tinggi. Hal tersebut terlihat dari seringnya memantau perkembangan peserta didik terutama dalam hal belajar.

\section{Pengembangan kemampuan Diri}

Pengembangan kemampuan diri guru masih kurang terlihat dari hasil penelitian ini, faktor terendahnya adalah dalam pengembangan kemampuan diri. Hal tersebut dapat dilihat dari hasil penelitian untuk indikator pelatihan yang diadakan sekolah dalam meningkatkan pengembangan diri dan sekolah memberikan pelatihan kepada guru dan karyawan, masingmasing memperoleh nilai 73,00 . 
Dalam mengembangkan guru dan staf, sekolah belum memberikan pelatihan secara rutin dan berkelanjutan untuk meningkatkan kompetensi guru. Sekolah masih lamban dan kurang konsen dalam meningkatkan pengembangan guru. Seminar, workshop dan pelatihan yang diadakan oleh pihak yayasan dan sekolah, hanya dilaksanakan satu kali dalam setahun, pada saat libur awal tahun ajaran. Adapun pelatihan yang dilaksanakan adalah pelatihan penyusunan silabus dan RPP. Pelatihan-pelatihan penunjang lainnya, sampai saat ini belum dilaksanakan oleh pinak sekolah.

\section{Perilaku Kerja yang Baik}

Guru merupakan orang yang digugu dan ditiru, oleh karena itu setiap gerak-gerik dan perilaku seorang guru menjadi panutan atau role model bagi siswa atau peserta didiknya.

Dalam hal perilaku kerja yang baik, terutama dalah hal menjaga moral, berperilaku sesuai dengan norma-norma setempat dan menjadi contoh dalam berperilaku, guru-guru di SMK Cyber Media Utama menunjukkan kriteria baik dengan rata-rata skor 73,67. Hal tersebut ditampilkan dengan menjaga kode etik sebagai seorang guru dan menjaga hubungan baik dengan siswa dan orang tua siswa baik melalui jalinan komunikasi yang baik. Namun demikian masih ada beberapa keluhan dari siswa dan orang tua mengenai hambatan informasi yang didapat dari guru atau sekolah mengenai informasiinformasi sekolah.

\section{Keinginan memberikan yang Terbaik}

Bersedia melakukan usaha di luar batas kewajaran untuk kesuksesan sekolah sering dilakukan oleh para guru terutama dalam hal membantu kegiatankegiatan yang berhubungan dengan mempromosikan sekolah, karena sekolah Cyber Media Utama baru pindah lokasi, sehingga masih banyak masyarakat sekitar yang belum mengenal dekat sekolah. selain itu, guru-guru juga sudah mengerahkan kemampuan dalam mengajar agar para peserta didik mampu menerima ilmu dan pengetahuan serta dapat memiliki kompetensi seperti harapan sekolah. Beberapa guru memiliki rasa tanggung jawab terhadap seluruh perkembangan peserta didik, dengan memberikan bimbingan dan tambahan waktu belajar pada waktu libur sekolah.

\section{Ketercapaian Tujuan Sekolah}

Pemelajaran yang diberikan sesuai dengan tujuan sekolah, dengan tingkat ketercapaian 77 , disebabkan karena perpindahan sekolah mengakibatkan beberapa sarana sekolah perlu diganti dan prasarana seperti gedung, lapangan, dan laboratorium masih dalam proses pembangunan. Keterbatasan tersebut, mengakibatkan proses belajar mengajar menjadi agak tersendat. Meskipun dalam keterbatasan, pemelajaran yang diberikan tetap mengedepankan keterampilan sebagai basis sekolah kejuruan. Ketercapaian nilai 81 menunjukkan bahwa pembelajaran 
yang diberikan membuat peserta didik lebih terampil. Hal tersebut juga ditunjukkan dengan keterlibatan peserta didik pada program praktek kerja lapangan di beberapa perusahaan di sekitar sekolah dan tanggapan positif dari perusahaan tersebut, serta keberlanjutan program praktek kerja lapangan ini untuk para adik kelas di tahun berikutnya.

\section{KESIMPULAN DAN SARAN}

Berdasarkan temuan penelitian dan pembahasan hasil penelitian tentang faktor-faktor yang mempengaruhi komitmen kerja guru di SMK Cyber Media Utama Kabupaten Bogor, Jawa Barat, dapat disimpulkan sebagai berikut.

1. Komitmen kerja di SMK Cyber Media Utama Kabupaten Bogor, Jawa Barat baik terlihat dari pencapaian skor rata-rata 71,61 pada kriteria tinggi.

2. Penyelesaian tugas merupakan faktor tertinggi dalam komitmen kerja guru dengan skor rata-rata 79,67 pada kriteria tinggi.

3. Pengembangan kemampuan diri merupakan faktor terendah dalam komitmen kerja guru dengan skor rata-rata 73,00 pada kriteria tinggi.

Berikut ini saran-saran peneliti:

1. Sekolah sebaiknya memberikan penghargaan kepada guru yang menyelesaikan tugas tepat waktu dan memberikan sanksi kepada guru yang tidak menyelesaikan tugas tepat waktu.

2. Sekolah sebaiknya memberikan pendidikan dan pelatihan kepada guru secara berkesinambungan dan berkelanjutan sebagai upaya pengembangan kemampuan diri guru.

3. keterlibatan guru dalam kegiatankegiatan sekolah lebih ditingkatkan, sehingga terlihat kepedulian guru terhadap nasib sekolah.

4. Program kerja guru sebaiknya diatur dan dijalankan sesuai dengan rencana yang telah ditetapkan.

\section{DAFTAR PUSTAKA}

Arikunto, Suharsimi. (2005). Manajemen Penelitian. Jakarta: Rineka Cipta.

Beyer, London E. (2002). Shooling, Moral Commitment and The Preparation of Teachers. Journal of Teacher Education, Vol 42 No. 3.

Bishop, J. W. (2000). Support Commitmen and Employee Outcomes in a Team Evironment. Journal of Managemen.

Deal, Jack. (2000). Human Resources:How to Creat Employee Loyalitiy, h.1 darihttp://www.Tsbj.Com/0304/0304-04.html.

Dwyer, William O. (1993). Critical Reviem of Behavior Invention to Treserve The Environment. New Delhi: Sage Publications.

Gibson, James L., John M. Ivancevich and James $H$. Donnelly, JR. (1997). Organizations: Behavior, Structure, Processes. USA: Richard D. Irvin.

Hamalik, Oemar. (2002). Pendidikan guru berdasarkan 
pendekatan kompetensi. Jakarta: PT Bumi Aksara.

Handoko, Hani T. (2000). Manajemen Personalia dan Sumberdaya Manusia. Yogyakarta: BPFE.

Hersey, P. K. (1996). Management of Organization Behavior: Utilizing Human Resources. New Jersey: Prentice-Hall, Inc.

Ivancevich, John M. (2007). Human Resources Management. New York: McGrraw-Hill International Edition.

Luthan, Fred. (2006). Perilaku Organisasi, Edisi 10. Alih
Bahasa, Vivin Andhika Yuwono, dkk.Yoyakarta: Andi.

Muhammad, Arni.(1996).Komunikasi Organisasi. Jakarta: Bumi Aksara.

P., R. S. (2006). Perilaku Organisasi. Jakarta: PT Indeks.

Robbins, Stephen P. (2006). Perilaku Organisasi, Edisi Kesepuluh, Alih Bahasa: Drs. Benyamin Molan. Jakarta: PT Indeks.

Zone, H. (2000). Employee Commitment. http: www: Hr.Zone.comArticle/Commitm en, html. 